\title{
STUDY OF PREPARATIONS OF BEE POLLEN EXTRACTS, ANTIOXIDANT AND ANTIBACTERIAL ACTIVITY
}

\author{
Estudo das preparações de extratos de pólen apícola, atividade antioxidante e antibacteriana
}

\author{
Solange Teresinha Carpes ${ }^{1}$, Rosicler Begnini ${ }^{2}$, Severino Matias de Alencar ${ }^{3}$, Maria Lúcia Masson ${ }^{4}$
}

\begin{abstract}
The aim of this study was to determine the antioxidant activity, phenolic content and antibacterial activity of pollen extracts obtained with different concentrations of ethanol. Each extraction condition (ethanol solutions from 40 to $90 \%$ ) had a different effect in the phenolic compounds content. Although, the pollen extract obtained at 60,70 and $80 \%$ of ethanol showed relatively higher levels of phenolic compounds (>10 mg/g) and did not present statistical significant difference between the extraction conditions. The amount of total phenolics ranged from 3.6 to 8.1 and 6.6 to $10.9 \mathrm{mg}$ GAE/g for Alagoas state and Parana state pollen, respectively. The higher value for antioxidant activity index was $83.30 \%$ for the pollen from Alagoas state and $81.15 \%$ for Parana state pollen. The highest degree of antioxidant activity was found in the extraction at $60 \%$ of ethanol solution for Parana state pollen, which also showed the highest concentration of polyphenol compounds. Staphylococcus aureus was inhibited by the ethanolic extract of Alagoas state pollen in all the concentrations of solvent, except the ethanolic extract of pollen at $90 \%$. The extract at $60 \%$ of ethanol solution (Parana sample) inhibited Bacillus subtilis, Pseudomonas aeruginosa and Klebsiella sp.
\end{abstract}

Index terms: Pollen, antioxidant, antibacterial activity.

\section{RESUMO}

Objetivou-se, neste estudo determinar compostos fenólicos, a atividade antioxidante a antibacteriana dos extratos etanólicos de pólen, obtidos com diferentes concentrações de etanol. As diferentes condições de extração (etanol de 40 a $90 \%$ ) apresentaram diferentes efeitos no conteúdo dos compostos fenólicos extraídos. Os extratos de pólen obtidos com etanol a 60, 70 e 80\% apresentaram maiores níveis de compostos fenólicos (>10 mg/g) e não apresentaram diferenças estatísticas entre essas condições de extração. A quantidade de compostos fenólicos nos extratos de pólen variou de 3.6 a 8.1 e 6.6 a $11 \mathrm{mg}$ de equivalente em ácido gálico por g de pólen (GAE), para os estados de Alagoas e Paraná, respectivamente. Os maiores índices de atividade antioxidante para o pólen do estado de Alagoas foi de $83.30 \%$ e $81.15 \%$ para o pólen do estado do Paraná. O pólen do estado do Paraná extraído com etanol a $60 \%$, apresentou o maior índice de atividade antioxidante e também a maior concentração de compostos fenólicos. A bactéria Staphylococcus aureus foi inibida pelo extrato etanólico do pólen de Alagoas, em todas as concentrações, exceto no extrato etanólico a $90 \%$. O extrato etanólico a 60\%, no pólen do Paraná, inibiu Bacillus subtilis, Pseudomonas aeruginosa e Klebsiella sp.

Termos para indexação: Pólen apícola, atividade antioxidante e antibacteriana.

(Received in jule 7, 2006 and approved in april 19, 2007)

\section{INTRODUCTION}

Pollen, as well as other apicultural products, has gained increased attention for its therapeutic properties, as antibacterial (GARCÍA et al., 2001; PROESTOS et al., 2005), antifungicidal (GARCÍA et al., 2001), anti-caryogenic (ALMAS et al., 2001) and immunomodulatory (GEBARA et al., 2002) effects. Other potential applications of pollen include its use in apitherapy and as a functional food in the food industry due to pollen nutritional properties. Bee gathered pollen is considered a valuable special food with varied enhancing effects in health (BOGDANOV, 2004).
The therapeutic action has been attributed to several phenolic compounds with antioxidant activity, present in these products. All bee-derived products such as honey, propolis and pollen have been applied for centuries in traditional medicine as well as in nutritional supplementation (ISLA et al., 2001).

The bioactive properties of apicultural pollen extracts can be increased using a solvent suitable for its extraction, improving the activity of free radicals sequestration (antirust activity) (DI PAOLA-NARANJO et al., 2004). Appropriate extracts of pollen can be used as

\footnotetext{
${ }^{1}$ Professora do Curso de Tecnologia em Processos Químicos - Universidade Tecnológica Federal do Paraná/UTFPR - Pato Branco - Paraná, Brasil _ Doutoranda em Tecnologia de Alimentos - Setor de Tecnologia de Alimentos - Universidade Federal do Paraná/UFPR - Jardim das Américas - Cx. P. 19011 81531990 - Curitiba, PR - solangecarpes@gmail.com

${ }^{2}$ Pós-Graduanda em Sistemas de Produção Tecnológica da Universidade Tecnológica Federal do Paraná/UTFPR - Pato Branco, PR, Brasil. ${ }^{3}$ Professor do Departamento de Agroindústria Alimentos e Nutrição/LAN - Escola Superior de Agricultura Luiz de Queiroz/ESALQ - Universidade Federal de São Paulo/USP.

${ }^{4}$ Professora do Setor de Tecnologia de Alimentos - Universidade Federal do Paraná/UFPR - Jardim das Américas - Cx. P. 19011 - 81.531 -990 - Curitiba, PR.
} 
functional food or alimentary supplement had the amount of phenolic composites and its capacity of sequestered the responsible free radicals for it carcinogenesis and stress oxidative (TANG et al., 2005).Pollen grains have specific characteristics according to the floral species or cultivation methods, but the quality depends on the collection process, cleanness, drying and storage applied by beekeepers with the objective to increase the product shelf-life.

Honey-bee collected pollen can be considered as a potential source of energy for human consumption. Pollen contains nutritional compounds like carbohydrates, proteins, amino acids, lipids, vitamins, minerals and traces of micronutrients (SERRA BONVEHÍ \& ESCOLÁ JORDÁ, 1997). In addition, pollen contains significant amounts of polyphenolic substances, mainly flavonoids (ALMEIDAMURADIAN et al., 2005). These phenolic compounds are essential for the plants physiology due to its contribution in the morphology (form and structure). The polyphenols are involved in plants growth and reproduction; they also supply resistance against pathogens by the action of the phytoalexins and protection against plagues increasing the astringency of the plant as a food, becoming indigestible to predators. The polyphenols constitute one of the most numerous metabolic groups of plants and are integral part of people and animals diet (COOK \& SAMMAN, 1996).

Until recently the interest in these compounds has been focused in the harmful effects on health caused by the ability of certain polyphenols to bind and precipitate macromolecules, such as proteins, carbohydrates and digestive enzymes, reducing the digestibility of foods. Nowadays, the interest in phenolic compounds has increased due to the antioxidant and free radical scavenging activities (DORMAN et al., 2003).

Several researchers found out that polyphenols are antioxidants with redox properties which allow them to act as reducing agents, hydrogen donators, and singlet oxygen quenchers (CALDWELL, 2003). The polyphenols also have metal chelation properties (RICE-EVANS et al., 1996). These compounds league metals to it (chelation of metals) and react with free radicals and genotoxic susbtances or carcinogenics (TANG et al., 2005). Epidemiologic studies have shown a correlation between an increased consumption of phenolics antioxidants and a reduced risk of cardiovascular disease and certain types of cancer (COOK \& SAMMAN, 1996).

The fact that French people have a low incidence of coronary heart disease, despite having a diet rich in fat and being heavy smokers, is also known to be correlated with wine consumption (KANNER et al., 1994). Despite much interest in the antioxidant activity of red wine, it is uncertain which of the phenols exhibit the greatest antioxidant effect (MINUSSI et al., 2003). These researchers showed a positive correlation between total phenolic and total antioxidant potential, for all wines analyzed. Some authors state the necessity of additional inquiries to evaluate the relative composition of polyphenolic substances in pollen and extracts of pollen, as well as the differences in its specification to evaluate its function and contribution regarding to the antioxidant activities (SERRA BONVEHÍ \& ESCOLÁ JORDÁ, 1997).

The aim of this work was to determine the phenolic content, antioxidant and antibacterial activities of pollen relating to the concentration of ethanol used as solvent. Pollen samples were collected in Parana and Alagoas states, in the south and northeastern regions of Brazil, respectively. The purpose of this study was also to demonstrate a possible relationship between phenolic content and antioxidant activity of pollen.

\section{MATERIALS AND METHODS}

\section{Preparation of pollen ethanolic extracts (PEE)}

The pollen samples $(2 \mathrm{~g})$ were milled, homogenized and extracted individually using $15 \mathrm{~mL}$ of ethanol solution as extraction solvent in different concentrations (PEE 40, PEE 50, PEE 60, PEE 70, PEE 80 and PEE 90\%) at temperature of $70^{\circ} \mathrm{C}$ for $30 \mathrm{~min}$ with constant agitation. The supernatant was separated and the solid residue was re-extracted. Then, the ethanol extracts of pollen were combined and stored at $5^{\circ} \mathrm{C}$ for further analysis. All samples were extracted in duplicate.

\section{Total phenolic content of pollen ethanolic extracts (PEE)}

Total polyphenols content was quantified according to the Folin-Ciocalteau spectrophotometric method using galic acid as reference standard (SINGLETON et al., 1965). In each sample of $0,5 \mathrm{~mL}, 2 \mathrm{~mL}$ (1:10 dilution) of FolinCiocalteau's reagent and $2 \mathrm{~mL}$ of $\mathrm{Na}_{2} \mathrm{CO}_{3}(4 \% \mathrm{w} / \mathrm{v})$ were added, storing this mixture in dark at room temperature for 2 hours. The absorbance of all samples was measured at 740 $\mathrm{nm}$ using a UV-VIS spectrophotometer. Results were expressed as milligrams of gallic acid equivalent per gram of dry weight of pollen (mg GAE/g dw) and are presented as the mean of duplicate analyses.

\section{Antioxidant activity of pollen ethanolic extracts (PEE)}

The antioxidant activity was determined by the oxidation of $\beta$-carotene and linoleic acid. $\beta$ - carotene 
(5 mg) (Sigma Co) was dissolved in $5 \mathrm{~mL}$ of chloroform and was pipetted into a flask containing $60 \mathrm{mg}$ of linoleic acid and $200 \mathrm{mg}$ of Tween 40 (polyoxyethylene sorbitan monopalmitate). The chloroform was removed using a rotoevaporator at $40^{\circ} \mathrm{C}$ for $5 \mathrm{~min}$; afterwards, $50 \mathrm{ml}$ of distilled water was added slowly with vigorous agitation to the residue, to form an emulsion. Aliquots of $1 \mathrm{~mL}$ of this emulsion were added to a tube containing $0.5 \mathrm{~mL}$ of PEE diluted 1:10, and the absorbance was measured at $470 \mathrm{~nm}$, immediately, against a blank, consisting of the emulsion without $\beta$-carotene. The tubes were placed in a water bath at $40^{\circ} \mathrm{C}$ and absorbance of all the samples at $470 \mathrm{~nm}$ were taken at zero time $(\mathrm{t}=0)$. Measurement of absorbance was continued until the color of $\beta$-carotene disappeared in the control reaction $(\mathrm{t}=180 \mathrm{~min})$ at $60 \mathrm{~min}$ intervals. The antioxidant activity of the extract was evaluated in terms of bleaching of $\beta$-carotene (ALENCAR, 2002). Antioxidant index (AI) was calculated using the following equation: $\mathrm{AI}=(\beta$-carotene content after $3 \mathrm{~h}$ of assay/initial $\beta$-carotene content) $x 100$

\section{Antibacterial activity of pollen ethanolic extracts (PEE)}

The disk diffusion assay described in detail by Bauer et al. (1966) was used in this study, with some modifications. The stock cultures of bacterials (Staphylococcus aureus ATCC 25.923, Bacillus cereus, Bacillus subtillis ATCC 21.332, Pseudomonas aeruginosa ATCC 15.442 and Klebsiella $s p$ ) were grown in nutrient broth (Difco Co) at $26-27^{\circ} \mathrm{C}$ for $24 \mathrm{~h}$ in a shaker. Aliquots of $40 \mu \mathrm{L}$ of pollen ethanolic extract were applied in paper disk and placed in plates containing nutrient agar that was previously inoculated with active cultures of these microorganisms with sterile swabs. Antibacterial activity was assessed by measuring the diameter of the inhibition zone around each disk after 24 hours of inoculation at $37^{\circ} \mathrm{C}$. The control $(40 \mu \mathrm{L}$ of ethanol) used in all the plates and extracts analized in duplicate. Gentamicin $(40 \mu \mathrm{L})$ was used as the positive control for bacteria.

\section{Statistical analysis}

Data were submitted to the analysis of variance (ANOVA). Tukey test was used to evaluate the significant differences between means (comparison of means) at the level of $\mathrm{p}<0.05$, using the software MSTAT-C (MSTAT-C, 1998). Correlation analyses of antioxidant activity (Y) versus total phenolic content $(\mathrm{X})$ were carried out using the correlation and regression program Statgraphics plus 4.1 and OriginPro 7.0 (OriginLabCorporation).

\section{RESULTS AND DISCUSSION}

\section{Total phenolic content of pollen ethanolic extracts (PEE)}

Several authors have found phenolic and flavonoid compounds in pollen (PROESTOS et al., 2005). Recent studies of total polyphenols in pollen collected by native bees of the region of Vienna in Austria indicated that the pollen collected by bees generally show characteristic amounts of total polyphenols with some variations due to its botanical origin.

Total phenolic compounds content of pollen extracts was solvent-dependent. The amount of total phenolics varied in different conditions of extraction and ranged from 3.6 to 8.1 and 6.6 to $10.9 \mathrm{mg} \mathrm{GAE} / \mathrm{g}$ of dry material to Alagoas and Parana pollen, respectively (Figures 1 and 2). The highest total phenolic levels were detected in pollen extracts from Parana samples (Figure 1). Figure 1 shows that each extraction condition had a different effect in the phenolic compounds content. Pollen extracted in ethanol at 60,70 and $80 \%$ of concentration showed relatively higher levels of phenolic compounds $(>10 \mathrm{mg} / \mathrm{g}$ ) and did not present significant difference between the extraction conditions.

Nevertheless, statistical difference was found between the other extraction conditions (40,50 and 90\%). These results showed that the extraction conditions (solvent concentrations) influenced the extraction of phenolic compounds of Parana pollen (Figure 1). Kroyer \& Hegedus (2001) achieved $8.2 \mathrm{mg} / \mathrm{g}$ of polyphenolics substances in natural bee-collected flower pollen, which could be significantly increased in the extracts $(21.4-24.6 \mathrm{mg} / \mathrm{g})$ with the highest content of total polyphenols in the ethanol extract.

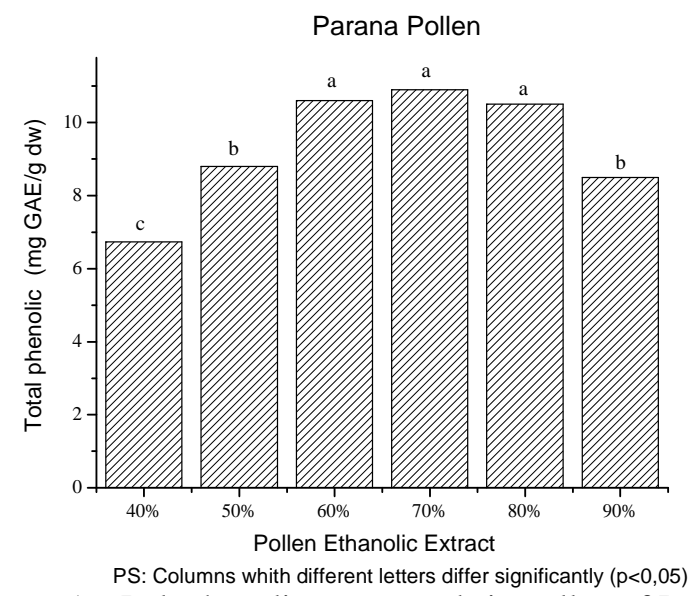

Figure 1 - Polyphenolic compounds in pollen of Parana state. 


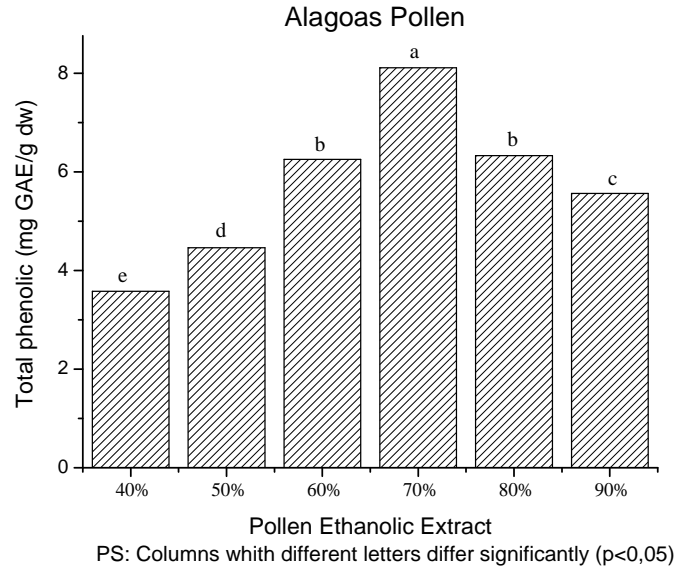

Figure 2 - Polyphenolic compounds in pollen of Alagoas state.

Comparing Figures 1 and 2, it can be observed that the content of total phenolic compounds of PEE 60, 70 and $80 \%$ from Parana pollen $(10.8,10.9$ and $10.6 \mathrm{mg} / \mathrm{g}$ ) was higher than the one from Alagoas $(6.2,8,1$ and $6.3 \mathrm{mg} / \mathrm{g}$,). The content of total phenolic compounds of Alagoas pollen varied from 3.6 to $8.1 \mathrm{mg} \mathrm{g}^{-1}$. Pollen extracted in ethanol at $70 \%$ of concentration showed relatively higher levels of phenolic compounds $(8.1 \mathrm{mg} / \mathrm{g})$ and have significant difference between the other extraction conditions (Figure 2). The ethanolic extractions performed in Alagoas pollen samples did not have significant differences between the treatment conditions, PEE at $60 \%$ and $90 \%$, in the level of 95\% according to the Tukey test.

The determination of total phenolic compounds through Folin-Ciocalteau method is important in many food materials. Folin-Ciocalteu reagent, a mixture of phosphotungstic $\left(\mathrm{H}_{3} \mathrm{PW}_{12} \mathrm{O}_{40}\right)$ and phosphomolybdic $\left(\mathrm{H}_{3} \mathrm{PMo}_{12} \mathrm{O}_{40}\right)$ acids, is reduced to blue oxides of tungstene $\left(\mathrm{W}_{8} \mathrm{O}_{23}\right)$ and molybdene $\left(\mathrm{Mo}_{8} \mathrm{O}_{23}\right)$ during phenol oxidation. Blue coloration is followed at $760 \mathrm{~nm}$ and reflects the quantity of polyphenols usually expressed as gallic acid equivalent (GAE) or catechin equivalent. This method was useful and rapid for evaluating pollen samples because bee pollen contains many kinds of phenolics (SERRA BONVEHÍ et al., 2001).

\section{Antioxidant activity of pollen ethanolic extracts (PEE)}

The $\beta$-carotene bleaching method is based on the loss of the yellow colour of $\beta$-carotene due to its reaction with radicals which are formed by linoleic acid oxidation in an emulsion. In this method, the $\beta$-carotene undergoes rapid discoloration in the absence of an antioxidant. The linoleic acid free radical formed upon the abstraction of a hydrogen atom from one of its diallylic methylene groups attacks the highly unsaturated $\beta$-carotene molecules. As a result, $\beta$-carotene will be oxidized and broken down in part, subsequently the system looses its chromophore and characteristic orange colour, which can be monitored spectrophotometrically (DORMAN et al., 2003).

The absorbances of all samples at $470 \mathrm{~nm}$ were taken at zero time and every $60 \mathrm{~min}$ until the color of $\beta$-carotene disappeared in the control reaction. The antioxidation index was calculated as being the reason the tax of bleaching of each group enters on the control tax.

In this work, the extracts from both samples of pollen were found to hinder the extent of $\beta$-carotene bleaching by neutralizing the linoleate free radical and other free radicals formed in the system. The antioxidant activity through $\beta$-carotene-linoleate model system of ethanol pollen extracts (40 to 90\%) are shown in Figures 3 and 4. The antioxidant ability of the control decreased drastically versus time.

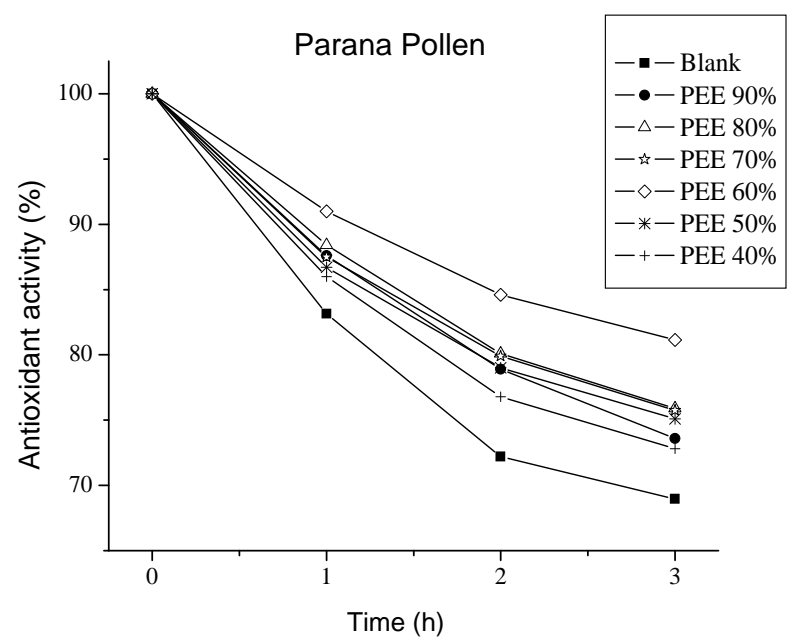

Figure 3 -Antioxidant activity (\%) of Parana state pollen.

All the extraction conditions with regard to the concentration of ethanol, presented some antioxidant activity, therefore they were superior to the control. The highest antioxidant activity index was found in the Alagoas pollen extracted with ethanol at $70 \%$, after 3 hours of treatment $(\mathrm{AA}=83.3 \%)$. Nevertheless, the highest degree of antioxidant activity was achieved in the PEE at $60 \%$ of Parana pollen, with index around $81 \%$ (Figures 3 and 4). This treatment condition also has the highest concentration 


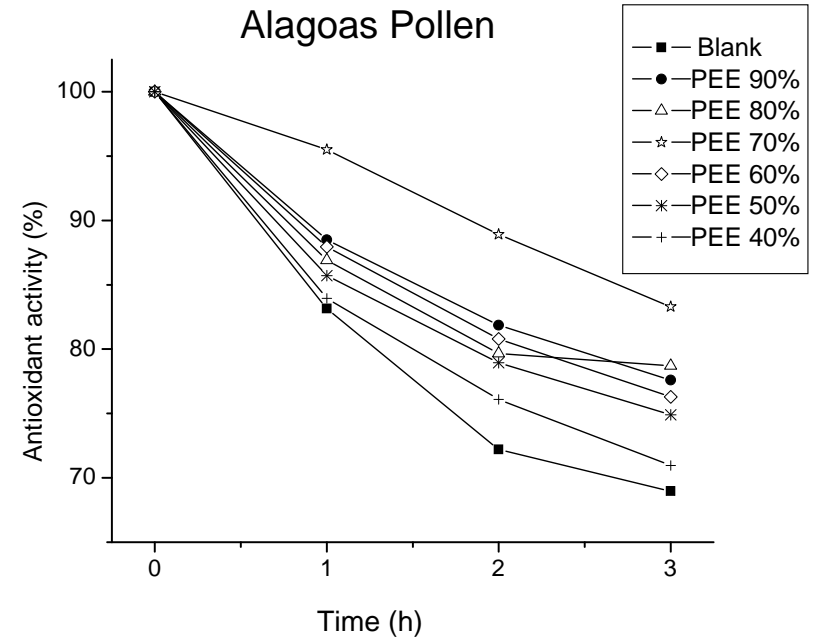

Figure 4-Antioxidant activity (\%) of Alagoas state pollen.

of polyphenol compounds, although low correlation between the content of total polyphenols and the antioxidant activity of the pollen preparations (Figure 5). The correlation between antioxidant activity $(Y)$ and total phenolic contents $(X)$ of ethanolic extracts of Parana pollen presented a correlation coefficient of $\mathrm{R}=0.73(Y=63.68$ $+1.28 \mathrm{X})$ and Alagoas pollen showed a correlation coefficient of $\mathrm{R}=0.78(Y=65.54+1.96 X)$ according to Figure 5. Theses results suggest that the antioxidant activity of Parana pollen and Alagoas pollen are influenced by the phenolic compounds (Figure 5). However other authors found that the antioxidant activity had a higher correlation $(71 \%)$ with total phenolic content in plant extracts of basil (Ocimum basilicum $\mathrm{L}$ ) which are used in the traditional medicine, as a culinary herb (JAVANMARDI et al., 2003).

\section{Antibacterial activity of pollen ethanolic extracts (PEE)}

Antibacterial activity of all pollen extract analized was according to the disk diffusion assay, and the results are shown in Tables 1 and 2. The PEE of Parana pollen at $60 \%$ shows the same inhibition degree against Bacillus subtilis, Pseudomonas aeruginosa and Klebsiella sp. Bacillus cereus and Staphylococcus aureus bacteria were not inhibited for Parana pollen in all extraction conditions

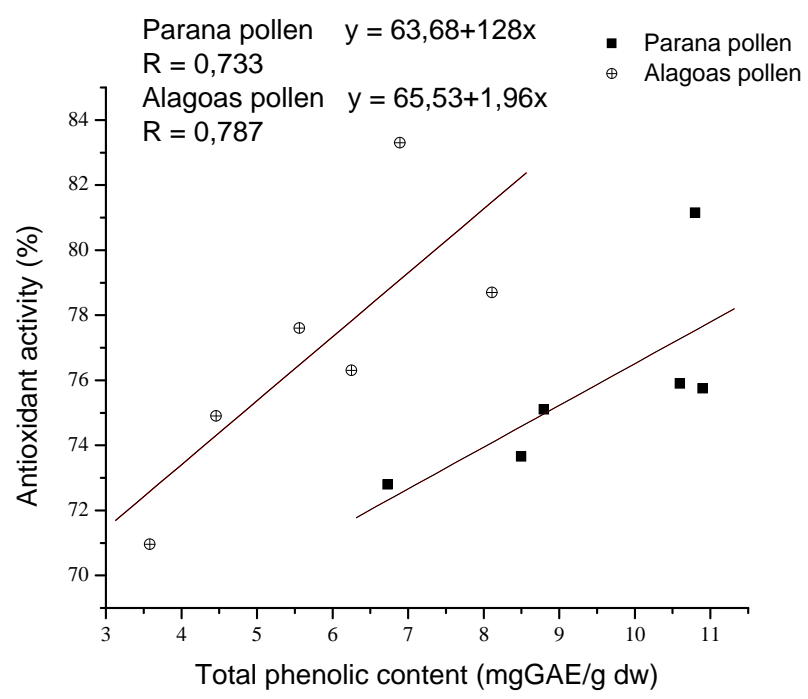

Figure 5 - Linear correlation of antioxidant activity versus total phenolic content of $40-90 \%$ ethanol concentration of Parana pollen and Alagoas pollen.

applied (different ethanol solution concentrations); however Bacillus cereus was inhibited by the pollen of Alagoas in PEE at 50 and $60 \%$ of ethanol. Bacillus subtilis bacteria were inhibited for Parana pollen in PEE at $40 \%$, $50 \%, 60 \%$ and $70 \%$ (Table 1) and for Alagoas pollen in PEE at $50 \%, 70 \%$ and $90 \%$ (Table 2). In this study, the PEE of Parana pollen at $90 \%$ showed the biggest clear zones around each disk $(7.0 \mathrm{~mm})$ against Klebsiella $s p$. Nevertheless, Klebsiella was also inhibited by the pollen from Alagoas in extracts of 60 and $70 \%$. The Alagoas extract pollen at $70 \%$, contained highest concentrations of phenolic content with antioxidant and antibacterial activity.

Pseudomonas aeruginosa bacteria were inhibited by $80 \%$ and $90 \%$ and Staphylococcus aureus bacteria were inhibited by extracts of pollen at 50\%, 60\%, 70\% and $80 \%$ of ethanol solution (Table 2). These different patterns of sensitivity are due to different phenolic compounds in pollen (ALMEIDA-MURADIAN et al., 2005).

Gentamicin was the antibiotic used for comparison, showing different ways of action to each bacterium. The control proved that the ethanol used in the extractions did not have inhibiting action. 
Table 1 -Antibacterial activity of Parana state pollen ethanolic extracts (PEE).

\begin{tabular}{cccccc}
\hline PEE $^{\mathrm{a}}$ & $\begin{array}{c}\text { Bacillus cereus } \\
(\mathrm{mm})^{c}\end{array}$ & $\begin{array}{c}\text { Bacillus subtilis } \\
(\mathrm{mm})\end{array}$ & $\begin{array}{c}\text { Pseudomonas } \\
\text { aeruginosas }(\mathrm{mm})\end{array}$ & $\begin{array}{c}\text { Staphylococcus } \\
\text { aureus } \\
(\mathrm{mm})\end{array}$ & $\begin{array}{c}\text { Klebsiella sp. } \\
(\mathrm{mm})\end{array}$ \\
\hline $40 \%$ & 0 & 0.5 & 0 & 0 & 0 \\
$50 \%$ & 0 & 4.0 & 0 & 0 & 0 \\
$60 \%$ & 0 & 2.0 & 2.5 & 0 & 2.5 \\
$70 \%$ & 0 & 3.0 & 1.5 & 0 & 3.5 \\
$80 \%$ & 0 & 0 & 0 & 0 & 7.0 \\
$90 \%$ & 0 & 0 & 0 & 0 & 0 \\
Control & 0 & 0 & 0 & 0 & 8.0 \\
$\mathrm{~A}^{b}$ & 8.0 & 11.0 & 8.5 & 9.0 & 0 \\
\hline
\end{tabular}

${ }^{a}$ PEE - Pollen Ethanolic Extract ${ }^{b}$ Antibiotic-gentamicin ${ }^{c}$ diameter of the inhibition zone ${ }^{*}$ ethanol ${ }^{a}$

Table 2-Antibacterial activity of Alagoas state pollen ethanolic extracts (PEE).

\begin{tabular}{cccccc}
\hline PEE & $\begin{array}{c}\text { Bacillus cereus } \\
(\mathrm{mm})^{c}\end{array}$ & $\begin{array}{c}\text { Bacillus subtilis } \\
(\mathrm{mm})\end{array}$ & $\begin{array}{c}\text { Pseudomonas } \\
\text { aeruginosas }(\mathrm{mm})\end{array}$ & $\begin{array}{c}\text { Staphylococcus } \\
\text { aureus } \\
(\mathrm{mm})\end{array}$ & $\begin{array}{c}\text { Klebsiella sp. } \\
(\mathrm{mm})\end{array}$ \\
\hline $40 \%$ & 0 & 0 & 0 & 0 & 0 \\
$50 \%$ & 0.5 & 0.5 & 0 & 1.0 & 0 \\
$60 \%$ & 0.5 & 0 & 0 & 1.5 & 3.5 \\
$70 \%$ & 0 & 2.0 & 1.0 & 1.5 & 0 \\
$80 \%$ & 0 & 0 & 1.0 & 0 & 0 \\
$90 \%$ & 0 & 2.0 & 1.0 & 0 & 0 \\
Control $^{*}$ & 0 & 0 & 8.5 & 9.0 & 8.0 \\
$\mathrm{~A}^{b}$ & 8.0 & 11.0 & 0 & 0 \\
\hline
\end{tabular}

${ }^{a}$ PEE - Pollen Ethanolic Extract $\quad{ }^{b}$ Antibiotic-gentamicin $\quad{ }^{c}$ diameter of the inhibition zone * ethanol

\section{CONCLUSION}

The content of total phenolic compounds in pollen extracts was found to be solvent-dependent. The best extraction conditions, relating to biological properties, were PEE at 70 ethanol solution. The amount of total phenolics varied in different conditions of extraction and ranged from 3.6 to 8.1 and 6.6 to $10.9 \mathrm{mg} \mathrm{GAE} / \mathrm{g}$ of dry material to Alagoas and Parana pollen, respectively. Although too little antibacterial activity was observed in extract of Parana pollen at $80 \%$ and $90 \%$ of ethanol, theses extracts showed higher amounts of total phenolic content with antioxidant activity above of $80 \%$. In such a way it is possible that the concentration of phenolic compounds does not determine the antibacterial activity, but the nature of phenolic compounds present in extracts. As different extracts exhibited different antioxidant and antibacterial activities, there may be different kinds of phenolic content in different pollen extract. According to the results obtained, pollen seems to have interesting biological properties, and can be considered as a functional food. Other studies will be necessary to establish quality parameters to standardize the Brazilian product. Due to the great biodiversity of Brazil, more studies are necessary for a better understanding of the functional properties of pollen.

\section{ACKNOWLEDGEMENTS}

We thank Dr. Henrique Brayer for suggestions and interest in this work. This work was supported by UTFPR, UFPR and PIDCT (CNPq). 


\section{BIBLIOGRAPHY}

ALENCAR, S. M. Estudo fitoquímico da origem botânica da própolis e avaliação da composição química de mel de Apis melífera africanizada de diferentes regiões do Brasil. 2002. 120 f. Tese (Doutorado) - Universidade Estadual de Campinas, Campinas, 2002.

ALMAS, K.; MAHMOUD, A.; DAHLAN, A. A comparative study of propolis and saline application on human dentin: a SEM study. Indian Journal Dentist Resourch, New Delhi, v. 12, p. 21-70, 2001.

ALMEIDA-MURADIAN, L. B.; PAMPLONA, L. C.; COIMBRA, S.; BARTH, O. M. Chemical composition and botanical evaluation of dried bee pollen pellets. Journal Food Composition and Analysis, Madison, v. 18, n. 1, p. 105-111, 2005.

BAUER, A. W.; KIRBY, W. M.; SHERRIS, J. C.; TURCK, M. Antiobiotic susceptibility testing by a standardized single disk method. American Journal of Clinical Pathology, [S.1.], v. 45, p. 493-496, 1966.

BOGDANOV, S. Quality and standards of pollen and beeswax. Apiacta, [S.1.], v. 38, p. 334-341, 2004.

CALDWELL, C. R. Alkylperoxyl radical scavenging activity of red leaf lettuce (Lactuca sativa $L$.) phenolics. Journal Agricultural Food Chemistry, Madison, v. 51, n. 16, p. 4589-4595, 2003.

COOK, N. C.; SAMMAN, S. Flavonoids: chemistry, metabolism, cardioprotective effects, and dietary sources. Journal Nutrition Biochemistry, [S.l.], v. 7, n. 2, p. 66-76, 1996

DI PAOLA-NARANJO, R. D.; SÁNCHEZ, J. S.; PARAMÁS, A. M. G.; GONZALO, J. C. R. Liquid chromatographic-mass spectrometric analysis of anthocyanin composition of dark blue bee pollen from Echium plantagineum. Journal Chromatography A, [S.1.], v. 1054, n. 1/2, p. 205-210, 2004.

DORMAN, H. J. D.; KOSAR, M.; KAHLOS, K.; HOLM, Y.; HILTUNEN, R. Antioxidant properties and composition of aqueous extracts from Mentha species, Hybrids, Varieties, and Cultivars. Journal Agricultural Food Chemistry, Easton, v. 51, n. 16, p. 4563-4569, 2003.

GARCÍA, M.; PÉREZ-ARQUILLUE, C.; JUAN, T.; JUAN,
M. I.; HERRERA, A. Note: pollen analysis and antibacterial activity of Spanish honeys. Food Science Technology International, Cambridge, v. 7, n. 2, p. 155-158, 2001.

GEBARA, E. C. E.; LIMA, L. A.; MAYER, M. P. A. Propolis antimicrobial activity against periodontopathic bacteria. Brazilian Journal Microbiology, São Paulo, v. 33, n. 4, p. 365-369, 2002.

ISLA, M. I.; MORENO, M. I. N.; SAMPIETRO, A. R.; VATTUONE, M. A. Antioxidant activity of Argentine propolis extracts. Journal of Ethnopharmacology, Lausanne, v. 76, n. 2, p. 165-170, 2001.

JAVANMARDI, J.; STUSHNOFF, C.; LOCKE, E.; VIVANCO, J. M. Antioxidant activity and total phenolic content of Iranian Ocimum accessions. Food Chemistry, London, v. 83 , n. 4 , p. $547-550,2003$.

KANNER, L.; FRANKEL, E.; GRANIT, R.; GERMAN, B.; KINSELLA, J. E. Natural antioxidants in grapes and wines. Journal Agricultural Food Chemistry, Easton, v. 42, n. 1, p. 64-69, 1994.

KROYER, G.; HEGEDUS, N. Evaluation of bioactive properties of pollen extracts as functional dietary food supplement. Innovative Food Science \& Emerging Techonologies, [S.1.], v. 2, n. 3, p. 171-174, 2001.

MINUSSI, R. C.; ROSSI, M.; BOLOGNA, L.; CORDI, L.; ROTILIO, D.; PASTORE, G. M.; DURAN, N. Phenolic compounds and total antioxidant potential of commercial wines. Food Chemistry, London, v. 82, n. 3, p. 409-416, 2003.

MSTAT-C. A microcomputer program for the design, management and analysis of agronomic research experiments. [S.1.]: Norway, 1998.

PROESTOS, C.; CHORIANOPOULOS, N.; NICHAS, G. J. E.; KOMAITIS, M. RP-HPLC analysis of the phenolic compounds of plant extracts: investigation of their antioxidant capacity and antimicrobial activity. Journal Agricultural Food Chemistry, Easton, v. 53, n. 4, p. 11901195, 2005.

RICE-EVANS, C. A.; MILLER, N. J.; PAGANGA, G. Structure antioxidant activity relationships of flavonoids and phenolic acids. Free Radical Biology and Medicine, [S.1.], v. 20, n. 7, p. 933-956, 1996. 
SERRA BONVEHÍ, J.; ESCOLÁ JORDÁ, R. Nutrient composition and microbiological quality of honeybeecollected pollen in Spain. Journal Agricultural Food Chemistry, Easton, v. 45, n. 3, p. 725-732, 1997.

SERRA BONVEHÍ, J.; SOLIVA TORRENTÓ, M.; CENTELLES LORENTE, E. Evaluation of polyphenolic and flavonoid compounds in honeybee-collected pollen produced in Spain. Journal Agricultural Food Chemistry, Easton, v. 49, n. 4, p. 1843-1853, 2001.
SINGLETON, V. L.; JOSEPH, A.; ROSSI, J. Colorimetry of total phenolics with phosphomolibdic-phosphotungstic acid reagents. American Journal of Enology and Viticulture, [S.1.], v. 16, p. 144-158, 1965.

TANG, B.; ZHANG, L.; GENG, Y. Determination of the antioxidant capacity of different food natural products with a new developed flow ingection spectrofluorimetry detecting hydroxyl radicals. Talanta, [S.1.], v. 65, n. 3, p. 769-775, 2005. 